\title{
Level Pemberian Tepung Rosella (Hibiscus sabdariffa Linn) Terhadap Kualitas Dendeng Babi
}

\section{Level of Roselle Flour (Hibiscus sabdariffa Linn) on the Quality of Pork Jerky}

\author{
Geertruida M. Sipahelut*, Heri Armadianto, Yakob R. Noach, Agustinus R. Riwu, Sutan Y. F. \\ Dillak, Junius R. L. Riwu \\ Fakultas Peternakan-Universitas Nusa Cendana, Kupang
}

\author{
Article history \\ Received: Sep 18, 2020; \\ Accepted: Jul 13, 2021 \\ * Corresponding author: \\ E-mail: \\ sipahelutetje@gmail.com \\ DOI: \\ 10.46549/jipvet.v11i2.148
}

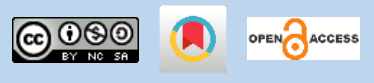

\begin{abstract}
The purpose of this research to determine the level on the quality of pork jerky (aroma, texture and TPC). The research design used was a complete random design (CRD) with 4 treatments and 3 replications, and continued with MannWhitney test. The sensoric data used hedonik test according to Kruskal-Wallis method. The treatment consisted of $\mathrm{R}_{0}=$ without roselle flour, $\mathrm{R}_{1}=$ roselle flour $5 \mathrm{~g}, \mathrm{R}_{2}=$ roselle flour $10 \mathrm{~g}$ and $\mathrm{R}_{3}=$ roselle flour $15 \mathrm{~g}$. The results showed that the addition of roselle flour $5 \mathrm{~g}, 10 \mathrm{~g}$ and $15 \mathrm{~g}$ gave a significant difference $(\mathrm{P}<0.05)$ to the aroma and TPC values while the texture had no significant effect $(\mathrm{P}>0,05)$. But the best texture value is at the level of $10 \mathrm{~g}$ roselle flour. Conclusion, The level of roselle flour influences the value of the aroma of jerky and can reduce the total bacterial growth in the pork jerky. The best activity level of $15 \mathrm{~g}$ roselle flour can reduce the lowest total bacterial colony.
\end{abstract}

Keywords: Aroma; Texture; TPC; Roselle flour; Pork jerky

\section{Abstrak}

Penelitian bertujuan untuk mengkaji level pemberian tepung Rosella (Hibiscus sabdariffa Linn) terhadap kualitas dendeng babi (aroma, tekstur dan total plate count/TPC). Rancangan yang digunakan adalah Rancangan acak lengkap (RAL) dengan 4 perlakuan dan 3 ulangan, dilanjutkan dengan uji MannWhitney. Data sensoris dianalisis menggunakan uji Hedonik menurut KruskalWallis. Perlakuan yang dicobakan terdiri dari $\mathrm{R}_{0}=$ tanpa pemberian tepung rosella (kontrol), $\mathrm{R}_{1}=$ tepung rosella $5 \mathrm{~g}, \mathrm{R}_{2}=$ tepung rosella $10 \mathrm{~g}$ dan $\mathrm{R}_{3}=$ tepung rosella $15 \mathrm{~g}$. Hasil penelitian menunjukkan bahwa pemberian tepung rosella pada level $5 \mathrm{~g}, 10 \mathrm{~g}$ dan $15 \mathrm{~g}$ memberikan perbedaan yang nyata $(\mathrm{P}<0,05)$ terhadap nilai aroma dan TPC sedangkan pada tekstur tidak berpengaruh nyata $(\mathrm{P}>0,05)$. Namun nilai tekstur terbaik adalah pada level pemberian tepung rosella $10 \mathrm{~g}$. Simpulan, level pemberian tepung rosella dapat berpengaruh terhadap nilai aroma, nilai tektur dendeng dan dapat menurunkan total koloni bakteri pada dendeng babi. Aktivitas level terbaik tepung rosella $15 \mathrm{~g}$ mampu menurunkan total koloni bakteri (TPC) terendah.

Kata kunci: Aroma; Dendeng babi; Tekstur; Tepung rosella; TPC 


\section{PENDAHULUAN}

Dendeng merupakan produk makanan berbentuk lempengan yang terbuat dari irisan atau gilingan daging segar dan berasal dari ternak sehat yang telah diberi bumbu dan dikeringan. Di Provinsi Nusa Tenggara Timur (NTT) umumnya dendeng yang diproduksi adalah dendeng iris (berbentuk lempengan). Umumnya dendeng dibuat dari daging sapi, namun di NTT juga dendeng dapat dibuat dari daging rusa, domba, maupun daging babi. Sebagai pangan tampilan dendeng (warna dan baunya) harus menarik selera konsumen dan merupakan faktor pertama terhadap produk tersebut.

Pengolahan dendeng dengan cara menambahkan rempah-rempah sebagai aromatik dan dikeringkan di bawah sinar matahari. Salah satu bahan rempah-rempah (bahan tambahan pangan) yang dapat digunakan dalam pembuatan dendeng adalah bunga rosella (Hibiscus sabdariffa Linn). Rosella merupakan salah satu tanaman yang dapat dimanfaatkan sebagai pengawet, karena mengandung antosianin, pigmen flavonoid yang berperan sebagai antioksidan dan mengandung senyawa hibiscetine yang membentuk pigmen warna ungu kemerahan sebagai antibakteri. Kelopak bunga rosella juga memiliki rasa masam yang unik menyegarkan karena memiliki dua komponen senyawa asam yang dominan yakni asam sitrat dan asam malat. Rosella dapat digunakan sebagai bahan makanan fungsionalnya sehingga menjadi potensial aplikasi di industri makanan (Tounkara et al, 2013).

Menurut Babalola et al. (2001), bahwa di dalam kelopak bunga rosella merah terdapat protein $17,4 \%$ vitamin C $63,5 \mathrm{mg} / 100 \mathrm{~g}$, abu $6,5 \%$. Penggunaan serbuk kering rosella pada daging olahan dapat menekan oksidasi lemak lebih baik dibandingkan penggunaan nitratnitrit (Bozkurt dan Belibagli, 2009). Menurut Handarini (2014) rosella dapat berfungsi sebagai pengawet alami, karena dapat menghambat pertumbuhan bakteri Salmonella sp, Coliform, mikrobia aerofilik pada daging segar.

Zat aktif yang paling berperan dalam kelopak bunga rosella meliputi gossypeti, antosianin dan glukosa hibiscis (Moeksin dan
Ronald, 2009). Antosianin memiliki sistem ikatan rangkap terkonjugasi yang mampu menjadikan antosianin sebagai antioksidan dengan mekanisme penangkapan radikal (Mardiah et al., 2009). Antioksidan bisa mempertahakan dan memberi perlindungan dari pengaruh radikal bebas (Suryanto dan Wehantaouw, 2009), sehingga mengurangi terjadinya kerusakan sel, seperti penuaan dini (anti-aging) (Sarbini, 2007).

\section{MATERI DAN METODE}

\section{LOKASI DAN WAKTU PENELITIAN}

Penelitian ini dilaksanakan di Laboratorium Teknologi Hasil Ternak Fapet Undana untuk pembuatan dendeng dan uji aroma, sedangkan pengujian tekstur dilakukan di Lab. CV. Chem-Mix, Bantul Jogyakarta. Untuk pengujian total koloni bakteri (TPC) dilakukan di Lab. Penyakit Tumbuhan, Fakultas Pertanian Undana Kupang. Penelitian dilaksanakan selama 2 bulan yang terdiri dari: persiapan alat dan bahan 1minggu, pra penelitian 1 minggu, analisa/pengujian sampel 1,5 bulan.

\section{MATERI PENELITIAN}

BAHAN

Bahan yang digunakan dalam penelitian ini adalah daging babi segar yang diperoleh dari meat shop khusus daging babi di kota Kupang. Daging yang dibutuhkan sebanyak $4 \mathrm{~kg}$ yang sudah dilakukan triming (tanpa kulit dan lemak), tepung rosella $30 \mathrm{~g}$, gula merah $1 \mathrm{~kg}$, bawang putih $250 \mathrm{~g}$, bawang merah $100 \mathrm{~g}$, ketumbar $100 \mathrm{~g}$, jintan $100 \mathrm{~g}$, jahe $100 \mathrm{~g}$, merica $12 \mathrm{~g}$, lengkuas $200 \mathrm{~g}$, garam dapur $100 \mathrm{~g}$, gula pasir $100 \mathrm{~g}$ dan asam jawa $400 \mathrm{~g}$.

ALAT

Alat yang digunakan dalam penelitian ini adalah, pisau, talenan, cobek, keranjang peniris, blender, oven, wadah plastik /baskom, gelas ukur, lemari pendingin/kulkas, plastik klip, dan timbangan digital Camry Elektronic Kitchen Scale EK3650 dengan tingkat akurasi 1g.

\section{METOdE PENELITIAN}

Rancangan percobaan yang digunakan dalam penelitian ini adalah Rancangan Acak Lengkap (RAL) yang terdiri dari 4 perlakuan dan 3 ulangan sehingga terdapat 12 unit 
percobaan, setiap unit percobaan menggunakan daging sebanyak $1 \mathrm{~kg}$. Unit percobaan sebagai berikut:

$\mathrm{R}_{0=}$ dendeng babi tanpa tepung rosella (kontrol)

$\mathrm{R}_{1}=$ dendeng babi menggunakan tepung rosella $5 \mathrm{~g}$

$\mathrm{R} 2$ = dendeng babi menggunakan tepung rosella $10 \mathrm{~g}$

R3 = dendeng babi menggunakan tepung rosella $15 \mathrm{~g}$

\section{PROSEDURPENELITIAN}

\section{Cara Pembuatan Tepung Rosella}

Kelopak bunga rosella dibersihkan, dipisahkan dari bijinya lalu dicuci, ditiriskan sebentar kemudian diiris menjadi ukuran yang lebih kecil. Selanjutnya dikeringkan dalam oven dengan suhu $40^{\circ} \mathrm{C}$ selama 3 hari, kemudian dihaluskan menggunakan blender lalu diayak untuk mendapatkan tepungnya.

\section{PROSES PEMbUATAN DENDENG}

Proses pembuatan dendeng meliputi empat tahap, yaitu persiapan bahan, pengirisan/penggilingan, pemberian bumbu dan pengeringan. Persiapan meliputi pemilihan daging dan melakukan triming pada lapisan lemak maupun urat. Pengirisan dimaksudkan untuk memperluas permukaan daging sehingga pengeringan akan lebih cepat.

\section{PERSIAPAN BAHAN}

Persiapan bahan meliputi bahan baku dan bahan tambahan yang terdiri dari berbagai macam bumbu. Daging yang telah disiapkan dilakukan pemisahan daging dari bagian tulang dan kulit sehingga diperoleh daging babi utuh, setelah proses pemisahan kemudian daging babi dicuci untuk menghilangkan sisa-sisa kotoran atau kontaminan yang mungkin terbawa saat proses pemisahan berlangsung.

\section{PENGIRISAN}

Pengirisan daging dapat dilakukan dengan dua cara, yaitu dengan diiris tipis dengan ketebalan 3-5 $\mathrm{mm}$ (sebelumnya daging dibekukan terlebih dahulu untuk mempermudah pada saat dilakukan pengirisan) atau digiling kemudian dicetak. Daging yang telah diiris tipis-tipis dipukul-pukul untuk mematahkan serat-serat daging sehingga daging menjadi lunak supaya dapat memudahkan bumbu-bumbu meresap ke dalam daging selama proses curing (Sutaryo, 2004).

PEMBERIAN BUMBU DAN MARINASI

Pemberian bumbu dan marinasi bertujuan untuk mempersiapkan daging pada penggunaan berikutnya, menghambat pertumbuhan mikroba, menimbulkan rasa enak. bentuk dari bahan mentah dan kandungan lemak yang menutupi daging (Sutaryo, 2004). Daging yang telah halus dicampur dengan bumbu dan gula kemudian diperam selama 1 hari. Alvarado et al. (2007) juga menyampaikan bahwa perendamang/marinasi daging yang dilakukan pada $\mathrm{pH}$ rendah $(\mathrm{pH}$ 4) dapat berfungsi menghambat bakteri patogen yaitu Listeria monocytogenes dan menurut Kamaldeep et al. (2012) merupakan bakteri patogen umum yang ditemukan pada daging. Bjorkroth (2005) menyatakan bahwa melakukan marinasi pada daging dapat meningkatkan keamanan pangan dan memperpanjang masa simpan produk.

\section{PENGOLAHAN DENDENG BABI}

1). Daging babi segar tanpa kulit dan tulang diambil dari bagian paha belakang; 2). Daging dipisahkan dari lemak, kemudian dicuci, ditiriskan dan dibekukan; 3). Daging disayat tipis dengan ketebalan $\pm 3-5 \mathrm{~mm}$ kemudian ditiriskan; 4). Daging dicampur dengan bumbu yang telah dihaluskan; 6). Selanjutnya pemberian tepung rosella, daging diperam (marinasi) semalam kemudian dikeringkan di bawah sinar matahari selama 3 hari; 7). Setelah kering dendeng ditimbang dan dikemas menggunakan plastik klip yang berukuran $1 \mathrm{~kg}$ dan diberi label sekaligus penimbangangan sampel untuk dianalisis.

\section{PARAMETER YANG DIUKUR}

\section{ORGANOLEPTIK}

Uji organoleptik dinilai dengan menggunakan skor skala hedonik (berbau khas dendeng, berbau khas dendeng dan sedikit berbau rosella, sedikit berbau dendeng dan sedikit berbau rosella, tidak berbau dendeng, tidak berbau rosella) dan skala numerik $(5,4,3,2,1)$ sesuai petunjuk Soekarto (1985). Panelis yang digunakan dalam penelitian ini adalah 11 orang. Setiap panelis sudah berpengalaman/terbiasa mengkonsumsi 
dendeng, dengan syarat yaitu sehat indra penciuman, perasa dan penglihatan.

\section{Aroma Daging}

a). Sampel dendeng babi diambil dari setiap kemasan yang telah diberi kode, diiris kecil-kecil lalu diletakkan di dalam piring sesuai perlakuan; b). Panelis langsung mencium aroma dendeng babi; c). Hasil penilaian ditulis pada kertas angket yang telah disediakan; d). Skor penilaian aroma adalah : 5 = berbau khas dendeng; $4=$ berbau khas dendeng dan sedikit berbau rosella; $3=$ sedikit berbau dendeng dan sedikit berbau rosella; $2=$ tidak tercium bau dendeng dan $1=$ tidak tercium bau rosella

\section{Tekstur}

Tekstur merupakan atribut bahan pangan sebagai penentu dipilihnya suatu bahan pangan tertentu. Menurut van Laack et al. (2001) keempukan daging merupakan suatu karakteristik kualitas yang kompleks yang dipengaruhi oleh banyak faktor, termasuk faktor biokimiawi sebelum dan setelah penyembelihan. Skor penilaian sebagai berikut: 1.) Skor 0-3 (halus); 2). Skor 3-6 (agak halus) dan 3). Skor $>6$ (kasar)

\section{TOTAL Plate COUNT (TPC)}

Metode Total Plate Count (TPC) dibedakan atas dua cara, yaitu metode tuang (pour plate), dan metode permukaan (surface /spread plate). Pada metode tuang, sejumlah sampel $(1 \mathrm{ml}$ atau o,1 $\mathrm{ml})$ dari pengenceran yang dikehendaki dimasukkan ke cawan petri, kemudian ditambahkan agar-agar cair steril yang didinginkan $\left(47-50{ }^{\circ} \mathrm{C}\right)$ sebanyak $15-20$ $\mathrm{ml}$ dan digoyangkan supaya sampelnya menyebar. Pada pemupukan dengan metode permukaan, terlebih dahulu dibuat agar cawan kemudian sebanyak $0,1 \mathrm{ml}$ sampel yang telah diencerkan dipipet pada permukaan media agar-agar tersebut. Kemudian diratakan dengan batang gelas melengkung yang steril selanjutnya di inkubasi $37{ }^{\circ} \mathrm{C}$ selama $2 \times 24$ jam. Jumlah koloni dalam sampel dapat dihitung sebagai berikut (Yunita, 2015).

$$
\text { Koloni } \mathrm{ml}=\text { jumlah koloni percawan } \frac{1}{\text { faktor pengencer }}
$$

\section{ANALISIS DATA}

Data tekstur dan TPC dianalisa menggunakan analisis varians (ANOVA) dan apabila terdapat pengaruh diantara perlakuan dilanjutkan dengan uji Duncan. Data aroma dinalisis menggunakan uji non parametrik Kruskal-Walis dan apa bila ada perbedaan dilanjut dengan uji Mann-Whitney (SPSS Versi 2017).

\section{HASIL DAN PEMBAHASAN}

\section{AROMA DENDENG BABI}

Berdasarkan penilaian panelis terhadap aroma dendeng babi diperoleh nilai rataan berkisar berkisar antara 5,00 sampai 2,33. Pemberian tepung rosella dengan level yang berbeda memberikan pengaruh yang nyata terhadap aroma dendeng babi. Nilai rata-rata aroma dendeng cenderung menurun seiring bertambahnya pemberian tepung rosella. Hasil pengamatan terhadap aroma dendeng babi disajikan pada Tabel 1.
Uji statistik menujukkan pemberian tepung rosella dengan level yang berbeda berpengaruh nyata $(\mathrm{P}<0.05)$ terhadap aroma dendeng babi. Dilanjutkan dengan hasil uji Mann-Whitney. Nilai rataan aroma dendeng babi tertinggi yaitu $5 \pm 0,00$ pada perlakuan $R_{0}$ tanpa penambahan tepung rosella dan $\mathrm{R} 1$ yaitu $4.33 \pm 1,56$ sebanyak 5g. Aroma yang dihasilkan yaitu aroma rempah-rempah dan sangat berbau khas dendeng babi. Nilai rataan aroma dendeng babi terendah yaitu $2.33 \pm 1,97$ pada perlakuan $R_{3}$ dengan penambahan tepung rosella 15 gram, membuat aroma yang dihasilkan kurang berbau/beraroma rempah (bau khas dendeng) tetapi sedikit beraoma khas rosella. Hal ini dapat disebabkan oleh sifat aroma khas yang dimiliki oleh rosella yang beraroma asam. Hal ini sesuai dengan pernyataan Rahardian (2017), yang menyatakan bahwa penambahan rosella mempengaruhi tingkat penerimaan aroma dendeng dimana aroma yang dihasilkan semakin beraroma asam sehingga kurang disukai panelis. 
Tabel 1. Rataan nilai skor aroma, tekstur dan TPC

\begin{tabular}{cccccc}
\hline \multirow{2}{*}{ Parameter } & \multicolumn{4}{c}{ Level Pemberian tepung rosella $(\mathbf{g})$} & \multirow{2}{*}{ P Value } \\
\cline { 2 - 5 } & $\mathbf{R 0}$ & $\mathbf{R 1}$ & $\mathbf{R 2}$ & $\mathbf{R 3}$ & \\
\hline Aroma & $5 \pm 0,00^{\mathrm{a}}$ & $4.33 \pm 1,56^{\mathrm{ab}}$ & $3.33 \pm 2,06^{\mathrm{bc}}$ & $2.33 \pm 1,97^{\mathrm{c}}$ & 0,003 \\
Tekstur & $6.97 \pm 2,31$ & $7.31 \pm 0,62$ & $9.05 \pm 0,44$ & $5.96 \pm 1,11$ & 0,109 \\
Total plate count & $123.33 \pm 18,90^{\mathrm{a}}$ & $97.33 \pm 1,53^{\mathrm{b}}$ & $93.33 \pm 6,43^{\mathrm{b}}$ & $48.33 \pm 3,06^{\mathrm{c}}$ & 0,000 \\
\hline
\end{tabular}

Keterangan :Superskrip yang berbeda pada baris yang sama menunjukan perbedaan yang nyata $(\mathrm{P}<0,05)$

Aroma merupakan salah satu parameter penilaian organoleptik terhadap suatu produk. Pada umumnya bau yang diterima oleh hidung dan otak lebih banyak merupakan berbagai ramuan atau campuran empat bahan utama yaitu harum, asam, tengik dan hangus (Winarno, 2008). Lebih lanjut dikatakan bahwa aroma daging yang diawetkan tergantung pada bahan pengawet yang digunakan. Aroma dendeng sangat khas dengan aroma bumbu rempah-rempah yang digunakan sepeti ketumbar, jintan, dan merica serta gula merah. Dendeng yang sudah kering aromanya akan semakin khas (Sutaryo et al., 2004)

\section{TEKSTUR DENDENG BABI}

Hasil analisis statistik menunjukkan bahwa pemberian tepung rosella tidak memberikan perberbedaan yang nyata $(\mathrm{P}>0.05)$ terhadap tekstur dendeng babi. Pada Tabel 1 menunjukkan bahwa pada perlakuan $\mathrm{R}_{3}$ dengan pemberian tepung rosella sebanyak 15 gram menghasilkan tekstur yang cukup lunak dengan rataan terendah $5.96 \pm 1,11$ sedangkan pada perlakuan $\mathrm{R}_{2}$ dengan pemberian tepung rosella sebanyak 10 gram menghasilkan tekstur yang alot (keras) dengan rataan tertinggi 9.05 $\pm 0,44$.

Tekstur pada daging dipengaruhi oleh ketebalan daging, cara pengirisan daging, jenis daging dan kadar air dari produk akhir. Berbagai perlakuan dalam penelitian ini menggunakn daging dengan ketebalan yang sama $\pm 5 \mathrm{~mm}$, pengirisan yang seragam (daging diiris berlawanan arah dengan serat daging) dan pemanasan yang seragam sehingga kadar air produk akhir yang dihasilkan seragam. Oleh karena itu, berbagai perlakuan tidak berpengaruh nyata terhadap tekstur dendeng babi. Menurut Van Laack et al. (2001) tekstur dan keempukan daging merupakan suatu karakteristik kualitas yang kompleks yang dipengaruhi oleh banyak faktor, termasuk faktor biokimiawi sebelum dan setelah penyembelihan.

Tekstur dendeng yang baik adalah semi basah tidak terlalu kering sehingga teksturnya empuk, tidak terdapat bercak putih dan kehijauan pada permukaannya (Sutaryo et al., 2004).

\section{TOTAL PLATE COUNT (TPC)}

Rataan TPC dendeng babi dapat dilihat pada Tabel 1. Hasil uji statistik menunjukkan bahwa pemberian tepung rosella terhadap TPC menunjukan perbedaan sangat nyata $(\mathrm{P}<0.01)$. TPC terendah terdapat pada dendeng babi yang mendapat perlakuan $\mathrm{R}_{3}: 48.33 \pm 3,06$ dan tertinggi terdapat pada perlakuan $\mathrm{R}_{0}$ : 123.33 $\pm 18,90$. Semakin tinggi level pemberian tepung rosella terhadap dendeng babi maka semakin rendah nilai TPC pada dendeng tersebut.

Rendahnya total bakteri pada perlakuan dengan pemberian tepung rosella $15 \mathrm{~g}$ menunjukkan bahwa rosella selain sebagai antioksidan rosella juga bisa berfungsi sebagai antibakteri yang baik. Hal ini disebabkan dalam rosella terdapat kelompok senyawa flavonoid yang berfungsi menghambat pertumbuhan mikroorganisme, karena senyawa-senyawa tersebut mampu membentuk senyawa kompleks dengan protein melalui ikatan hidrogen, kelompok senyawa seperti antosianin merupakan kelompok bahan alam pada tumbuhan yang berperan sebagai antioksidan, antimikroba, antialergi dan anti inflamatori (Pietta, 2000). Tingginya total jumlah bakteri pada perlakuan tanpa pemberian tepung rosella disebabkan tidak adanya komponen antimikroba tepung rosella.

Rosella mengandung senyawa flavonoid yang memiliki aktivitas antibakteri. Senyawa 
ini menghambat proses metabolisme pada bakteri sehingga menyebabkan kematian pada bakteri. Sesuai dengan pernyataan Cowan (1999), bahwa flavonoid memiliki kemampuan dalam menghambat aktivitas bakteri dengan membentuk kompleks dengan struktur tertentu pada dinding sel bakteri sehingga menyebabkan kematian pada bakteri. Selain itu, rosella juga mengandung senyawa asam yang dapat menghambat pertumbuhan bakteri.

\section{KESIMPULAN}

Pemberian tepung rosella pada level yang berbeda menurunkan nilai aroma, tidak mempengaruhi nilai tekstur namun tekstur terbaik adalah $10 \mathrm{~g}$ dan dapat menurunkan total koloni bakteri pada dendeng babi. Level pemberian tepung rosella terbaik pada penelitian ini untuk pembuatan dendeng babi adalah $15 \mathrm{~g} / \mathrm{kg}$ daging segar.

\section{DAFTAR PUSTAKA}

Alvarado C and Mc Kee S. 2007. Marination to improve functional properties and safety of poultry meat. J. Appl Poultry Res. 16: 113-120. DOI: 10. 1093/japr/16.1.113.

Babalola SO, Babalola AO and Aworh OC. 2001. Compositional Attributes of the Calyces ofRosella (Hibiscus sabdariffa L.). The Jurnal of Food Technology in Africa. 6 (4):133-134

Bjorkroth J. 2005. Microbiologycal ecology of marinated meat products. Int Meat Sci. 70:477-480. DOI: 10.1016/0168-1605(96) 01135-X.

Bozkurt H and Belibagli K. 2009. Use of Rosemary and Hibiscus sabdariffa Linn inProductionOf Kavurma, a Cooked Meat Produck. Jurnal of the Science of

Food and Agriculture. 89:1168

Cowan MM. 1999. Plant Products as Antimicrobial Agents. Clinical Microbiology Reviews.

Evanuarini H dan Huda. 2011. Quality of Dendeng Giling on Different Sugar addition. Jurnal Ilmu-Ilmu Peternakan. 21(2): $1-10$

Handarini. 2014. Potensi Ekstrak Bunga Rosella (Hibiscus sabdariffa L.) Sebagai pengawet alami yang diaplikasikan pada daging ayam segar pengganti formalin. Jurnal Agroknow. Vol. 2(1): 1-7

Kamaldeep KU, Kelly JKG, Elizabeth AEB, Nigel MH, April SS, Lobaton S and Bruce B. 2012. Effect of packaging and storage time on survival of Listeriamonocytogenes onkipper-ed beef steakand Turkey tenders. $J$ Food Sci. 71: M57-M60. DOI: 10.1111/j.1750-3841. 2011.02485.x.

Mardiah, Amelia L dan Sulaiman A. 2009. Ekstraksi Kulit Batang Rosella (Hibiscus Sabdariffa L.) Sebagai pewarna merah alami. Jurnal Pertanian. Vol. 1(1): 1-8

Moeksin R dan Ronald SH. 2009. Pengaruh Kondisi, perlakuan dan berat sampel terhadap ekstraksi antosianin dari kelopak bunga Rosella dengan pelarut aquadest dan ethanol. Jurnal Sains dan Matematika (JSM), Vol. 16, 11-18.

Pietta PG. 2000. Flavonoids as Antioxidants. Journal of Natural Product. 63, 10361042. H. DOI 10.1021/np 999904509lu

Rahadian R, Harun N dan Raswen E. 2017. Pemanfaatan Ekstrak Kelopak Bunga Rosella (Hibiscus sabdariffa Linn) dan Rumput Laut (Euchema cottoni) Terhadap Mutu Permen Jelly. JOM Faperta UR. Vol. 4(1): 1-14

Sarbini D. 2007. Optimalisasi Dosis Ekstrak Bunga Rosella Merah (Hibiscus Sabdariffa Linn) sebagai anti-aging Aterosklerosis untuk menghambat aktifasi NF-k $\beta$, TNF- $\alpha$ dan ICAM-1 pada kultur sel Endothel yang dipapar Low Density Lipoprotein Teroksidasi. Jurnal Penelitian Sains dan Teknologi. Vol. 8(2): 99-109.

Soekarto ST. 1985. Penilaian organoleptik: untuk industri pangan dan hasil pertanian. Bhratara Karya Aksara, Jakarta.

Soeparno. 2009. Ilmu dan Teknologi Daging. Cetakan ke lima. Gajah Mada University Press. Yogyakarta.

Sutaryo S dan Sri M. 2004. Pengetahuan Bahan Olahan Hasil Ternak dan Standar Nasional Indonesia (SNI). Makalah disajikan dalam Rangka Pelatihan Penerapan Jaminan Mutu di Balai Pengembangan Sumber Daya Masyarakat Peternakan. KomplekTaru Budaya Ungaran.

Tounkara F, Sodio B, Amza T, Wei-Le G and Hui-Shi Y. 2013. Antioxidant Effect and Watter-Holding Capacity of Roselle 
(Hibiscus sabdariffa L.) Seed Protein Hydrolysates. Journal of Food Science and Technology. 5 (6) : 752-757

Van Laack R, Stevens SG and Stalders KJ. 2001. The influence of ultimat $\mathrm{pH}$ and intramuscular fat content on pork tenderness and tenderization. J. Anim. Sci. 79: 392-397.

Suryanto E dan Wehantouw F. 2009. Aktivitas Penangkap Radikal Bebas dari Ekstrak Fenolik Daun Sukun (Artocarpus altilis F.) Chem. Prog. Vol. 2(1): 1-7
Winarno FG. 2008. Kimia Pangan dan Gizi Edisi Terbaru. Bogor. M-brio Press

Yunita M, Hendrawan Y dan Yulianingsih R. 2015. Analisis Kuantitatif Mikrobiologi Pada Makanan Penerbangan (Aerofood ACS) Garuda Indonesia Berdasarkan TPC (Total Plate Count) Dengan Metode Pour Plate. Jurnal Keteknikan Pertanian Tropis dan Biosistem. Vol. 3: 237-248. 